\title{
Inoculation of Plant Growth Promoting Bacteria Ochrobactrum intermedium, Brevibacterium Sp. and Bacillus cereus Induce Plant Growth Parameters
}

\author{
Muhammad Faisal \\ Department of Microbiology and Molecular Genetics, University of the Punjab, \\ Quaid-e-Azam Campus, Lahore-54590, Pakistan
}

Tel: 92-42-35952811 Fax: 92-42-99230481,E-mail: mohdfaysal@yahoo.com

Received: March 15, 2013 Accepted: June 28, 2013 Published: July 1, 2013

doi: 10.5296/jab.v1i1.3698 URL: http://dx.doi.org/10.5296/jab.v1i1.3698

\begin{abstract}
The impact of chromate resistant bacteria Ochrobactrum intermedium, Brevibacterium sp. and Bacillus cereus was observed on Lens esculenta plant under two different concentration of $\mathrm{K}_{2} \mathrm{CrO}_{4}\left(0\right.$ and $\left.300 \mu \mathrm{g} \mathrm{ml}^{-1}\right)$. Bacterial inoculations enhanced the seed germination while chromium alone reduced seed germination (60\%) and emergence (10\%). About 27 and 21\% reduction in root and shoot length was recorded at $300 \mu \mathrm{g} \mathrm{ml}^{-1}$ of $\mathrm{K}_{2} \mathrm{CrO}_{4}$. Chromium salt drastically reduced root and shoot length, number and weight of grains per pod, and number and weight of grains per plant, but bacterial strains enhanced these parameters. Plant accumulates chromium in its root and fewer amounts are transferred into shoot, leaves and pod.
\end{abstract}

Keywords: Bacillus cereus, Brevibacterium, Chromium, Ochrobactrum intermedium, Heavy Metals, Lens esculenta

\section{Introduction}

Chromate is one of the poisonous polluting metals, discharged from effluents of various industries like leather tanning, metal finishing industry, alloy preparation (Ozdemir et al., 2005). Attention has increased from different organizations due to the hazardous impact of this metal on the biological life (Zayed \& Terry, 2003). Many investigators have reported the deleterious impact of chromate salt on various plant parameters; however, the requirement of chromium for plant growth is still not understood. In nature chromium mainly exists as trivalent and hexavalent form. The mobility and uptake of hexavalent chromium is more in plants and animals as compared to trivalent chromium which is less mobile and bioavailable (Amezcua-Allieri et al., 2005).

Chromium mostly occurs as $\mathrm{Cr}$ (III) and $\mathrm{Cr}$ (VI). Cr (VI) is more mobile and permeable to 
cells and is taken up by plants so enters into the food chain (Bluskov et al., 2005). So there must be some mechanism which limits the hexavalent chromium mobility and permeability. Various bacterial strains are now identified which can convert hexavalent chromium in-to trivalent chromium (Mabbett et al., 2002). Bacterial strains residing in the soil especially near the vicinity (rhizosphere) of plants helps their growth parameters by providing more minerals protection against harmful pathogens and enhancing their plant growth parameters (Kapulnik, 1996). Heavy metals released from the industrial accumulate in the residing agricultural soil which becomes hazardous for living fauna and flora (Bhogal et al., 2003). These metals are accumulated in our body when we used crops which are grown in such metal contaminated soil and ultimately cause chronic diseases (Soisungwan et al., 2003). Trivalent chromium is considered as important micronutrient for human body but it is less toxic (Bahijri \& Mufti, 2002) as compared to hexavalent chromium which is toxic, mutagenic and carcinogenic (Ortegel et al., 2002). Several investigators have reported the positive impact of bacterial inoculation on plant growth. In this study we will check the impact of chromate resistant/reducing bacterial strains was observed on different morphological and biochemical parameters of plant in presence of chromium.

\section{Methods}

\subsection{Bacterial Strains Used}

Three chromate reducing strains (Ochrobactrum intermedium, Brevibacterium and Bacillus cereus) already identified by Faisal and Hasnain $(2004,2005)$ were tried to inoculate the Lens esculenta seed in the field experiments. These strains were isolated from effluents of tanneries. Strains were maintained on nutrient agar plates supplemented with $1000 \mu \mathrm{g} \mathrm{ml}^{-1}$ of $\mathrm{K}_{2} \mathrm{CrO}_{4}$ in acetate minimal medium (Pattanapipitpaisal et al., 2001).

\subsection{Germination Experiments}

Certified seeds of Lens esculenta were collected from NARC, Islamabad, Pakistan. Seeds were surface sterilized in 5\% sodium hypochlorite solution for 5 minutes and then completely rinsed with distilled water thrice. Chromium was used as $\mathrm{Cr}$ (VI) salt $\mathrm{K}_{2} \mathrm{CrO}_{4}$ with a concentration of $300 \mu \mathrm{g} \mathrm{ml}^{-1}$. Seed were inoculated with bacterial strains for dipping the seed in bacterial suspension for 15 minutes. Control seed were dipped in glass distilled water for the same time period. Seeds were sown uniformaly. The pots were watered regularly and seed germination and seedling emergence was recorded regularly. After maturity plants were harvested and various parameters (root length, shoot length, weight and number of grains per pod as well as the weight and number of grains per plant) were measured. For chromium estimation Lens esculenta seedlings were washed and oven dried at $80^{\circ} \mathrm{C}$ for 24 hours. This oven dried material was crushed following Humphries (1975). Chromium content was estimated by using the classical spectrophotometric method following Rand et al. (1979). Trivalent chromium was estimated by first oxidizing it in to hexavalent chromium with $\mathrm{KMnO}_{4}$ and then by using the above described spectrophotometric method.

\section{Results}

\subsection{Seed Germination}

Reduction of $60 \%$ was observed in seed germination in case of chromium supplemented control with respect to non inoculated control (Table 1). Strains Ochrobactrum intermedium, 
Brevibacterium and Bacillus cereus increased the germination 6, 9 and 12\%, respectively, as comparison to un-inoculated controls. At $300 \mu \mathrm{g} \mathrm{ml}^{-1}$ of chromium stress, almost 20, 40 and $40 \%$, increases in seed germination were observed with strains Ochrobactrum intermedium, Brevibacterium and Bacillus cereus, respectively. Maximum stimulation (48\%) in seed germination was obtained in case of mix inoculation under chromium stress (Table 1).

Table1. Effect of inoculation of chromium resistant bacteria on seed germination, Seedling emergence, Root and shoot length of Lens esculenta plant at 0 and $300 \mu \mathrm{g} \mathrm{ml}^{-1} \mathrm{~K}_{2} \mathrm{CrO}_{4}$ concentrations (Means of three replicates)

\begin{tabular}{ccccc}
\hline \multirow{2}{*}{ Strains } & \multicolumn{2}{c}{ Seed germination (\%) } & \multicolumn{2}{c}{ Seed emergence } \\
\cline { 2 - 5 } & $\mathbf{0}$ & $\mathbf{3 0 0}$ & $\mathbf{0}$ & $\mathbf{3 0 0}$ \\
& $\boldsymbol{\mu \mathbf { g ~ m l } ^ { - 1 }}$ & $\boldsymbol{\mu \mathbf { g ~ m l } ^ { - 1 }}$ & $\mu \mathbf{g ~ m l}^{-\mathbf{1}}$ & $\mu \mathbf{g ~ m l}^{-\mathbf{1}}$ \\
\hline Control & $80 \pm 4.1$ & $50 \pm 3.2$ & $50 \pm 2.8$ & $45 \pm 2.5$ \\
O. intermedium & $85 \pm 3.8$ & $60 \pm 2.8$ & $70 \pm 3.0$ & $60 \pm 4.2$ \\
Brevibacterium $\mathbf{~ s p}$ & $87 \pm 5.1$ & $70 \pm 3.0$ & $80 \pm 2.4$ & $70 \pm \pm 3.8$ \\
B. cereus & $90 \pm 3.7$ & $70 \pm 3.0$ & $90 \pm 4.0$ & $70 \pm 2.8$ \\
Mix culture & $95 \pm 4.0$ & $95 \pm 2.7$ & $90 \pm 3.8$ & $80 \pm 4.5$ \\
\hline
\end{tabular}

\subsection{Seedling Emergence}

A reduction of $10 \%$ was observed in percentage emergence in case of chromium stressed control. Bacterial inoculation caused an early seedlings emergence as comparison to un-inoculated controls. Strain B. cereus increased the percentage emergence $80 \%$, with respect to its controls. Mixed culture showed more effect on this entire factor, while $O$. intermedium showed less in this regard (Table 1).

\subsection{Root Length}

About $27.2 \%$ reduction in root length was noticed under chromate stress as compared to non-inoculated control (Table 2). Three strains showed different effect on the plant individually. At $0 \mu \mathrm{g} \mathrm{ml}^{-1}$ of chromium, B. cereus proved more effective as compared to other two strains and it was proved that it increased the root length by $32 \%$, while with mixed culture, Brevibacterium and O. intermedium enhanced the root length 36.8, 18.4 and 12.6\%, respectively. Almost same trend was observed under chromium stress.

\subsection{Shoot Length}

In case of shoot length there was a decrease of $21 \%$ under chromium stress as compared to control. All strains enhanced this growth parameter both under chromium stress and without stress. At $0 \mu \mathrm{g} \mathrm{ml}^{-1}$ of chromium, O. intermedium, Brevibacterium, B. cereus and mixed culture enhanced the shoot length $11.4 \%, 10.9 \%, 12.6 \%$ and $14.7 \%$, respectively (Table 2). 
Table 2. Effect of inoculation of chromium resistant bacteria on root and shoot length of Lens esculenta plant at 0 and $300 \mu \mathrm{g} \mathrm{ml}^{-1} \mathrm{~K}_{2} \mathrm{CrO}_{4}$ concentrations (Means of three replicates)

\begin{tabular}{ccccc}
\hline \multirow{2}{*}{ Strains } & \multicolumn{2}{c}{ Root length $(\mathbf{c m})$} & \multicolumn{2}{c}{ Shoot length $(\mathbf{c m})$} \\
\cline { 2 - 5 } & $\mathbf{0}$ & $\mathbf{3 0 0}$ & $\mathbf{0}$ & $\mathbf{3 0 0}$ \\
& $\mu \mathbf{g ~ m l}^{-\mathbf{1}}$ & $\mu \mathbf{g ~ m l}^{-\mathbf{1}}$ & $\mu \mathbf{g ~ m l}^{-1}$ & $\mu \mathbf{g ~ m l}^{-1}$ \\
\hline Control & $10.3 \pm 0.7$ & $7.5 \pm 0.1$ & $10.3 \pm 0.7$ & $7.5 \pm 0.1$ \\
O. intermedium & $11.6 \pm 0.6$ & $8.3 \pm 0.2$ & $11.6 \pm 0.6$ & $8.3 \pm 0.2$ \\
Brevibacterium $\mathbf{s p .}$ & $12.2 \pm 0.5$ & $8.7 \pm 0.3$ & $12.2 \pm 0.5$ & $8.7 \pm 0.3$ \\
B. cereus & $13.6 \pm 0.7$ & $7.5 \pm 0.2$ & $13.6 \pm 0.7$ & $7.5 \pm 0.2$ \\
Mix culture & $14.1 \pm 0.5$ & $9.5 \pm 0.1$ & $14.1 \pm 0.5$ & $9.5 \pm 0.1$ \\
\hline
\end{tabular}

\subsection{Number of Pods Per Plant}

$50 \%$ reduction in number of pods was noticed under chromate stress as compared to without stress (Table 3). These strains proved stimulatory effect on this parameter. Brevibacterium increased the number of pods up to $50 \%$ and rest of the three strains increased this parameter up to $100 \%$. Under chromium stress bacterial inoculation was most effective (Table 3 ).

Table 3. Effect of inoculation of chromium resistant bacteria on number of pod plant $^{-1}$ and number of grain pod $^{-1}$ of Lens esculenta at 0 and $300 \mu \mathrm{g} \mathrm{ml}^{-1} \mathrm{~K}_{2} \mathrm{CrO}_{4}$ concentrations (Means of three replicates)

\begin{tabular}{|c|c|c|c|c|}
\hline \multirow[b]{2}{*}{ Strains } & \multicolumn{2}{|c|}{ Number of pod plant ${ }^{-1}$} & \multicolumn{2}{|c|}{ Number of grain pod ${ }^{-1}$} \\
\hline & $\begin{array}{c}0 \\
\mathrm{mg} \mathrm{ml}^{-1}\end{array}$ & $\begin{array}{c}300 \\
\mathrm{mg} \mathrm{ml}^{-1}\end{array}$ & $\begin{array}{c}0 \\
\mathrm{mg} \mathrm{ml}^{-1}\end{array}$ & $\begin{array}{c}300 \\
\mathrm{mg} \mathrm{ml}^{-1}\end{array}$ \\
\hline Control & $2 \pm 0.08$ & $1 \pm 0.06$ & $1 \pm 0.05$ & $0 \pm 0.0$ \\
\hline O. intermedium & $4 \pm 0.09$ & $4 \pm 0.07$ & $2 \pm 0.06$ & $0 \pm 0.0$ \\
\hline Brevibacterium sp & $3 \pm 0.07$ & $3 \pm 0.08$ & $2 \pm 0.04$ & $1 \pm 0.04$ \\
\hline B. cereus & $4 \pm 0.07$ & $2 \pm 0.06$ & $3 \pm 0.08$ & $0 \pm 0.0$ \\
\hline Mix culture & $4 \pm 0.1$ & $3 \pm 0.1$ & $2 \pm 0.09$ & $1 \pm 0.03$ \\
\hline
\end{tabular}

\subsection{Number of Grains Per Pods}

In case of number of grains per pod under hexavalent chromium stress, a $100 \%$ reduction was recorded. At $0 \mu \mathrm{g} \mathrm{ml}^{-1}$ of chromium $O$. intermedium, Brevibacterium and mixed culture showed an increase of $100 \%$ in number of grains, while B. cereus gave an increment of $200 \%$ for this parameter (Table 3). Under hexavalent chromium stress strain O. intermedium and $B$. cereus did not show any impact in number of pods while Brevibacterium and mixed culture showed an increase of $100 \%$ when compared to non-inoculated respective control.

\subsection{Weight of Pods Per Plants}

Almost $32 \%$ reduction in the weight of pod was observed under chromium stress. The inoculation of these strain enhanced the weight of pods in both under chromium stress and without stress. Without chromium stress $O$. intermedium and mixed culture showed an increase of $16.6 \%$ in weight of pods per plant, while B. cereus and Brevibacterium showed an 
increase of 33.33 and $31.42 \%$, respectively (Table 4 ).

Table 4. Effect of inoculation of chromium resistant bacteria on weight of pod plant $^{-1}$ and weight of grain pod ${ }^{-1}$ of Lens esculenta at 0 and $300 \mu \mathrm{g} \mathrm{ml}^{-1} \mathrm{~K}_{2} \mathrm{CrO}_{4}$ concentrations (Means of three replicates)

\begin{tabular}{|c|c|c|c|c|}
\hline \multirow{2}{*}{ Strains } & \multicolumn{2}{|c|}{$\begin{array}{c}\text { Weight of pod plant } \\
\text { (g) }\end{array}$} & \multicolumn{2}{|c|}{$\begin{array}{c}\text { Weight of grain pod } \\
\text { (g) }\end{array}$} \\
\hline & $\begin{array}{c}\mathbf{0} \\
\mathrm{mg} \mathrm{ml}^{-1}\end{array}$ & $\begin{array}{c}300 \\
\mathrm{mg} \mathrm{ml}^{-1}\end{array}$ & $\begin{array}{c}\mathbf{0} \\
\mathrm{mg} \mathrm{ml}^{-1}\end{array}$ & $\begin{array}{c}300 \\
\mathrm{mg} \mathrm{ml}^{-1}\end{array}$ \\
\hline Control & $0.030 \pm 0.002$ & $0.02 \pm 0.001$ & $0.030 \pm 0.002$ & $0.02 \pm 0.001$ \\
\hline O. intermedium & $0.035 \pm 0.004$ & $0.029 \pm 0.001$ & $0.035 \pm 0.004$ & $0.029 \pm 0.001$ \\
\hline Brevibacterium sp & $0.046 \pm 0.003$ & $0.029 \pm 0.001$ & $0.046 \pm 0.003$ & $0.029 \pm 0.001$ \\
\hline B. cereus & $0.04 \pm 0.001$ & $0.029 \pm 0.002$ & $0.04 \pm 0.001$ & $0.029 \pm 0.002$ \\
\hline Mix culture & $0.035 \pm 0.002$ & $0.025 \pm 0.001$ & $0.035 \pm 0.002$ & $0.025 \pm 0.001$ \\
\hline
\end{tabular}

\subsection{Weight of Grains Per Pods}

In case of this parameter $100 \%$ reduction was observed in control plants under chromium stress. The inoculation of these strain enhanced the weight of grains to different extents in both type of treatments. Under hexavalent chromium stress mixed culture and Brevibacterium showed $12 \%$ and $14 \%$ increase in weight of grains per pod, respectively, while other strains showed no effect (Table 4).

\subsection{Weight of Grains Per Plant}

A reduction of $25 \%$ in total grain weight was recorded in chromate stress in comparison to chromate free control. At $0 \mu \mathrm{g} \mathrm{ml}^{-1}$ of chromium, mixed culture and Brevibacterium increased the grain weight up to $10 \%$ while strains Ochrobactrum intermedium and Bacillus cereus increased up to 7 and $10 \%$, respectively. In case of chromium stress, inoculated plants showed increase in weight of grain per plant from 25 to $35 \%$.

\subsection{Chromium Content}

Chromium content was measured by Humphries (1975) method to check the chromium level in different parts and its reduction. Bacterial inoculation caused a reduction in chromate uptake in plants roots as compared to un-inoculated control (Figure 1). Optimum accumulation of chromate was observed in root and then in shoot, leaves and pods. Almost 80 to $90 \%$ less chromium was detected in root of inoculated plants as compare to control. Here it was obvious that all the strains successfully reduced most bioavailable hexavalent chromium in to trivalent chromium. A significant reduction in chromium content of shoots was observed. A reduction (60 to $80 \%$ ) in chromium content was observed in inoculated plants in comparison to control. All strains reduced chromium to a greater extent and there was $11.05 \%$ less chromium in shoot than leaves. In leaves a significant reduction of chromium was observed (Figure 1). 

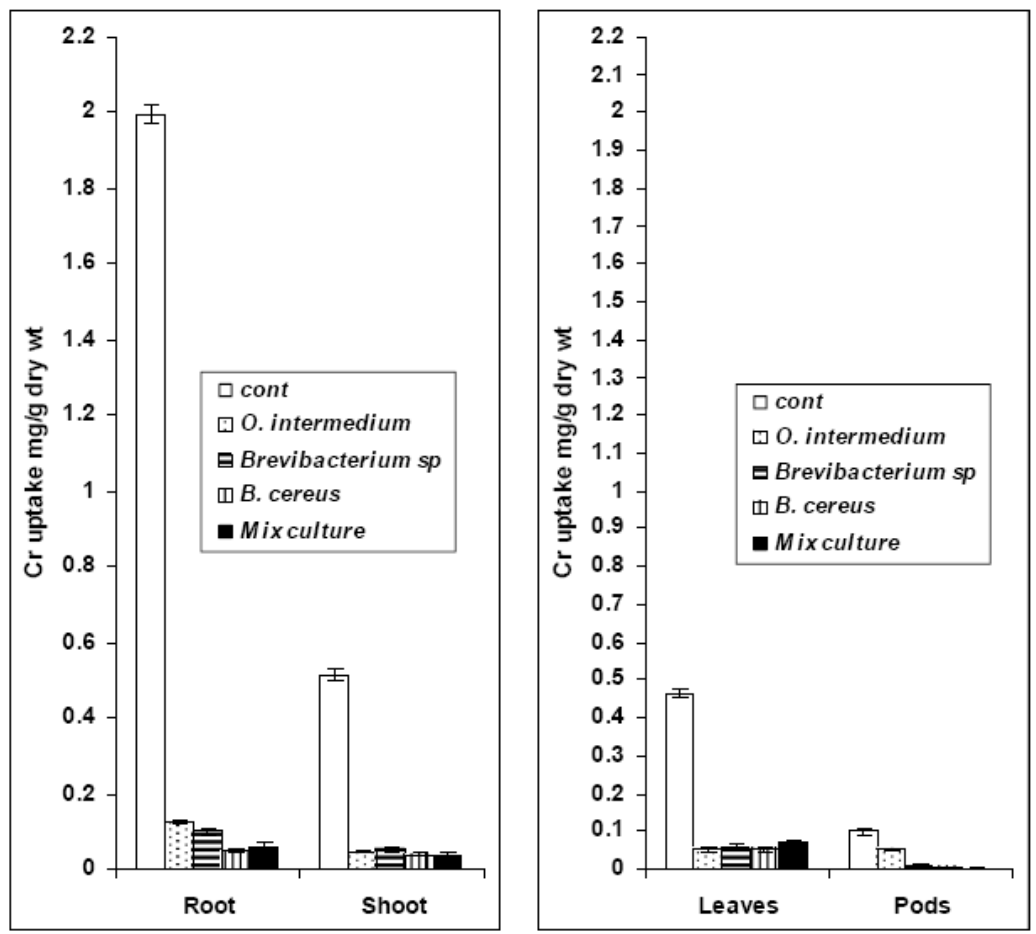

Figure 1. Effect of inoculation of $\mathrm{Cr}(\mathrm{VI})$-reducing bacteria on chromate uptake ( $\mathrm{mg} \mathrm{Cr} \mathrm{g}^{-1}$ dry weight) in lens plants when initially supplied with $300 \mu \mathrm{g} \quad \mathrm{ml}^{-1}$ of $\mathrm{K}_{2} \mathrm{CrO}_{4}$

\subsection{Statistical Analysis}

Results obtained in these experiments were analyzed statistically following Steel and Torrie (1981).

\section{Discussion}

In the present investigation three chromate reducing bacteria (Ochrobactrum intermedium, Brevibacterium and Bacillus cereus) which were previously isolated by Faisal and Hasnain (2004, 2005. These strains exhibit very high level resistance against chromium in rich and minimal medium. Majority of them could tolerate up to $40 \mathrm{mg} \mathrm{K}_{2} \mathrm{CrO}_{4} \mathrm{ml}^{-1}$ on nutrient agar and 2-10 $\mathrm{mg} \mathrm{K}_{2} \mathrm{CrO}_{4} \mathrm{ml}^{-1}$ in acetate-minimal medium. These strains could tolerate high level of chromate in both media. Camargo et al. (2003) isolated chromate resistance Bacillus which can tolerate up to $2.5 \mathrm{mg} \mathrm{Cr}$ (VI) $\mathrm{ml}^{-1}$. Strains reported by Kourtev et al. (2007) showed a resistance level of $10 \mathrm{mM}$ of $\mathrm{K}_{2} \mathrm{CrO}_{4}$.

Plant microbe interaction is now days getting much importance. These strains showed improvements in different growth aspects Lens esculenta. In this study, effects of chromate salts and different bacterial strains were observed both under chromium stress and unstressed conditions in pot experiments. Seed germination of Lens esculenta was adversely affected due to application of chromate salt (hexavalent). Beside this others workers also documented the adverse impact of chromate salt on seed germination (Manjula \& Podile, 2005). Cobalt and chromate caused a reduction in seed germination at the highest concentration and significantly retard radicle growth which may be due to toxic impact of chromium and cobalt on the efficacy of amylases and its movement of sugars to the Phaseolus vulgaris embryo 
axes (Zeid, 2001).

The effect of hexavalent chromium salt was much severe on the non-inoculated plants. Inoculated seed have more germination percentage as compared to un-inoculated controls. Under chromium stress all three strains significantly improve seed germination in comparison to un-inoculated controls. Enhanced seed germination in cereals and some vegetable was noticed when inoculated with bacteria (Domenech et al., 2006; Faisal \& Hasnain, 2005). Marked reduction in root length was noticed in chromate treated plants while bacterial inoculation gives some enhancement in this parameter even in the presence of chromate. Same results were observed in case of shoot length. Significant decrease in yield parameters was observed with $300 \mu \mathrm{g} \mathrm{ml}^{-1}$ of chromium stress in comparison to control. In Bacopa monnieri chromium salt caused a reduction in the various biochemical parameters in pot experiments (Pande et al., 2007). In Vigna radiata chromium drastically affect the yield parameters as compared to chromium free controls (Faisal \& Hasnain, 2005). Much amount was accumulated in the root part while little amount of chromium was transferred to shoot and leaves. Hexavalent chromium can easily cross the biological membranes and in root cells it is converted in to trivalent chromium which is less mobile. More amounts of various metals is accumulated in lower part of plants such as root while less amount was transferred to the upper parts that is leaves and shoot (Citterio et al., 2003).

These three strains (Ochrobactrum intermedium, Bacillus cereus and Brevibacterium sp) lessen the toxic impact of chromate by decreasing the availability to the plants by converting the toxic hexavalent chromium into less toxic trivalent chromium.

\section{References}

Amezcua-Allieri, M., Lead, J., \& Rodriguez-Vazquez, R. (2005). Changes of chromium behavior in soil during phenanthrene removal by Penicillium frequentans. BioMetals, 18, 23-29. http://dx.doi.org/10.1007/s10534-004-5771-y

Bahijri, S. M. A., \& Mufti, A. M. B. (2002). Beneficial effects of chromium in people with type 2 diabetes, and urinary chromium response to glucose load as a possible indicator of status. Biological Trace Element Research, 85, 97-110. http://dx.doi.org/10.1385/BTER:85:2:097

Bhogal, A., Nicholson, F. A., Chambers, B. J., \& Shepherd, M. A. (2003). Effects of past sewage sludge additions on heavy metal availability in light textured soils: implications for crop yields and metal uptakes. Environmental Pollution, 121, 413-423. http://dx.doi.org/10.1016/S0269-7491(02)00230-0

Bluskov, S., Arocena, J., Omotoso, O., \& Young, J. (2005). Uptake, distribution, and speciation of chromium in Brassica juncea. Internation Journal of Phytoremediation, 7, 153-165. http://dx.doi.org/10.1080/16226510590950441

Camargo, F. A., Okeke, B. C., Bento, F. M., \& Frankenberger, W. T. (2003). In vitro reduction of hexavalent chromium by a cell free extracts of Bacillus sp. ES 29 stimulated by $\mathrm{Cu}\left({ }^{2+}\right)$. Applied Microbiology Biotechnology, 62, 569-573. http://dx.doi.org/10.1007/s00253-003-1291-x 
Citterio, S., Santagostino, A., Fumagalli, P., Prato, N., Ranalli, P., \& Sgorbati, S. (2003). Heavy metal tolerance and accumulation of $\mathrm{Cd}, \mathrm{Cr}$ and $\mathrm{Ni}$ by Cannabis sativa L. Plant \& Soil, 256, 243-252. http://dx.doi.org/10.1023/A:1026113905129

Doménech, A., Torres, F. J., de Sola, E. R., \& Alarcón, J. (2006). Electrochemical detection of high oxidation states of chromium (IV and V) in chromium-doped cassiterite and Tin-sphene ceramic pigmenting Systems. European Journal of Inorganic Chemistry, 6, 638-648. http://dx.doi.org/10.1002/ejic.200500775

Faisal, M., \& Hasnain, S. (2004). Comparative study of $\mathrm{Cr}(\mathrm{VI})$ reduction in industrial effluent by Ochrobactrum intermedium vs. Brevibacterium sp. Biotechnology Letters, 26, 1623-1628. http://dx.doi.org/10.1007/s10529-004-3184-1

Faisal, M., \& Hasnain, S. (2005). Microbial Cr (VI) reduction concurrently improves Helianthus annuus growth. Biotechnology Letters, 27, 943-947. http://dx.doi.org/10.1007/s10529-005-7188-2

Humphries, E. C. (1975). Mineral Component and ash analysis. In K. Paech \& M. Y. Traley (Eds.), Modern methods of plant analysis, Springer Verlag, Berlin, Gothigen Heidelberg.

Kapulnik, Y. (1996). Plant growth promotion by rhizobacteria. (In: Waisel et al. (Eds.), Plant roots, the hidden half (pp.769-781). New York: Marcel Dekker.)

Kourtev, P. S., Nakatsu, C. H., \& Konopka, A. (2006). Responses of the anaerobic bacterial community to addition of organic $\mathrm{C}$ in Chromium(VI)- and Iron(III)-amended microcosms. $\begin{array}{llll}\text { Applied and } \quad \text { Environmental } & \text { Microbiology, } & \text { 72, }\end{array}$ http://dx.doi.org/10.1128/AEM.72.1.628-637.2006

Mabbett, A. N., Lloyd, J. R., \& Macaskie, L. E. (2002). Effect of complexing agents on reduction of $\mathrm{Cr}(\mathrm{VI})$ by Desulfovibrio vulgaris ATCC 29579. Biotechnology \&. Bioengineering, 79, 389-397. http://dx.doi.org/10.1002/bit.10361

Manjula, K., \& Podile, A. (2005). Increase in seedling emergence and dry weight of Pigeon Pea in the field with chitin-supplemented formulations of Bacillus subtilis AF 1. World Journal of Microbiology and Biotechnology, 21, 1057-1062. http://dx.doi.org/10.1007/s11274-004-8148-z

Ortegel, J. W., Staren, E. D., Fabe, L. P., Warren, W. H., \& Braun, D. P. (2002). Modulation of tumor-infiltrating lymphocyte cytolytic activity against human non-small cell lung cancer. Lung Cancer, 36, 17-25. http://dx.doi.org/10.1016/S0169-5002(01)00472-X

Ozdemir, C., Karatas, M., Dursun, S., Argun, M. E., \& Dogan, S. (2005). Effect of $\mathrm{MnSO}_{4}$ on the chromium removal from the leather industry wastewater. Environmental Technology, 26, 397-400. http://dx.doi.org/10.1080/09593332608618551

Pande, P., Chand, S., Yadav, V., Anwar, M., \& Patra, D. D. (2007). Influence of chromium with vermicompost on growth and accumulation by Brahmi. Communication in. Soil Science \&. Plant Analysis, 38, 2815-2829. http://dx.doi.org/10.1080/00103620701663057 


\section{Macrothink}

Pattanapipitpaisal, P., Brown, N. L., \& Macaskie, L. E. (2001). Chromate reduction by Microbacterium liquefaciens immobilized in polyvinyl alcohol. Biotechnology Letters, 23, 61-65. http://dx.doi.org/10.1023/A:1026750810580

Rand, M. C., Arnod, E., \& Michel, J. (1979). Standard methods for the examination of water and wastewater. American Public Health Association.

Soisungwan, S., Baker, J. R., Urbenjapol., S., Haswell-Elkins, M., Reilly, P. E. B., Williams, D. J., \& Moore, M. R. (2003). A global perspective on cadmium pollution and toxicity in nonoccupationally exposed population. Toxicology Letters, 137, 65-83. http://dx.doi.org/10.1016/S0378-4274(02)00381-8

Steel, R. G. D., Torrie, J. H. (1981). A Biometrical Approach. In: Principles and Procedures of Statistics (2nd ed.). McGraw Hill International Book Company.

Zayed, A. M., \& Terry, N. (2003). Chromium in the environment: factors affecting biological remediation. Plant \& Soil, 249, 139-156. http://dx.doi.org/10.1023/A:1022504826342

Zeid., I. M. (2001). Responses of Phaseolus vulgaris chromium and cobalt treatments. Biol Plant., 44, 111-115. http://dx.doi.org/10.1023/A:1017934708402

\section{Copyright Disclaimer}

Copyright reserved by the author(s).

This article is an open-access article distributed under the terms and conditions of the Creative Commons Attribution license (http://creativecommons.org/licenses/by/3.0/). 